\title{
Instytucjonalne wsparcie innowacyjności miast w województwie śląskim
}

\section{Institutional Support of City Innovation in Silesia}

Streszczenie: Polskie miasta borykają się z wieloma problemami o charakterze zarówno gospodarczym, jak i społecznym. Po pierwsze, muszą przystosować się do zmian, jakie czekają miasta w całej Europie, startując z pozycji dużo słabszej niż miasta bardziej rozwiniętych krajów Unii Europejskiej - przede wszystkim ze względu na zaniedbania infrastrukturalne. Po drugie, dotykają je takie same problemy społeczne, obecne w całej Europie, a zwłaszcza bezrobocie wśród absolwentów uniwersytetów i szkół wyższych. Potencjalnym sposobem ich rozwiązywania są oczywiście pieniądze, ale również otwartość na innowacje.

Innowacyjność miast może być rozpatrywana na różne sposoby. Zwykle zwraca się uwagę na obecność określonych instytucji, które dzięki różnym mechanizmom finansowym i pozafinansowym wspierają komercjalizację technologii, obecność przedsiębiorstw w większości wytwarzających wysokie technologie, poziom absorpcji funduszy unijnych stanowiący kryterium przy ocenie gmin w konkursach zmierzających do wyodrębnienia ośrodków innowacyjnych, np. Krajowi Liderzy Innowacji i Rozwoju. Instytucje spełniające tego typu zadania działają, i to z powodzeniem, w województwie śląskim. Są to przede wszystkim jednostki badawczo-rozwojowe, parki przemysłowe oraz naukowo-technologiczne oraz instytucje otoczenia biznesu. Celem artykułu jest próba zaprezentowania ich roli w miastach województwa śląskiego na podstawie zebranych materiałów. Na wstępie wyjaśniono kluczowe pojęcia odnoszące się do innowacyjności.

Abstract: Polish cities deal with a lot of economic as well as social problems. First of all, they have
to adapt to the changes that occur all around Europe. They start from a much worse position than the
better developed cities of the European Union, mainly because of infrastructural negligence. Secondly,
the cities deal with same problems as other European cities, especially the unemployment of univer-
sity graduates. The potential solution for this situation is not only money, but also a favorable attitude
towards innovations.
City innovation can be examined in different ways. Usually the presence of particular institutions is
taken into consideration. Thanks to various financial and non-financial mechanisms, the institutions
support commercialization of technology, the presence of companies producing high technology and
the use of Union fund that determines which cities become centres of innovation in different contests,
e.g. Leaders of Innovation and Development. Such institutions function in Silesia and are very success- 
ful. These are mainly research and development entities, industrial and science-technology parks and also institutions of business environment. The article is written for the purpose of showing how important the institutions are in Silesia. At the beginning the key words relating to innovation are explained.

Słowa kluczowe: innowacja, instytucje, miasta, Śląsk

Key words: innovation, institutions, cities, Silesia

\section{POJĘCIE I ROLA INNOWACYJNOŚCI W WYBRANYCH KONCEPCJACH TEORETYCZNYCH}

We współczesnych gospodarkach zachodzą dynamiczne i wielopłaszczyznowe przekształcenia. Ich głównym źródłem są przemiany cywilizacyjne, których rezultatami są m.in. proces globalizacji oraz innowacje (Maśloch, 2005). W wielu państwach obserwuje się wewnątrzregionalny wzrost na skutek innowacji wdrażanych w przedsiębiorstwach, zwłaszcza tych, które funkcjonują w skupiskach, czyli klastrach. Dlatego też innowacja, szczególnie technologiczna, stanowi podstawowy czynnik polaryzacji rozwoju regionów i miast (Szostak, 2011).

Innowacje to wszelkiego rodzaju zmiany, celowo wprowadzane przez człowieka lub przez niego zaprojektowane, które polegają na zastępowaniu dotychczasowych stanów rzeczy innymi (Dworak, 2012; Jasiński, 1997; Kochmańska, 2011). Innowacje to także wszelkie procesy twórczego myślenia zmierzające do zastosowania i użytkowania ulepszonych rozwiązań w technice, technologii, organizacji, życiu społecznym, politycznym itp. (Campion, 2012). Obejmują całokształt przeobrażeń w działaniu i funkcjonowaniu podmiotów gospodarczych (Janczewski, 2006) i jednostek terytorialnych. Najczęściej można się spotkać z szerszym i węższym pojmowaniem innowacji. W pierwszym z nich, utożsamia się omawiane pojęcie $z$ dobrami, które są uznawane za nowe. W tym kontekście zwykle przytacza się definicje innowacji zaproponowane przez J. Schumpetera (1960: 104), dla którego są to nowe wyroby, procesy produkcyjne lub już udoskonalone, może to być także zupełnie odmienny sposób sprzedaży lub zakupów, powołanie do życia nowego rynku, zastosowanie innych surowców bądź półfabrykatów albo wprowadzenie innej organizacji produkcji. W drugim z zaproponowanych ujęć, węższym, przyjmuje się, że innowacje to pionierskie wprowadzenie bądź zastosowanie nowego produktu, procesu, systemu lub urządzenia (Jasiński, 1997: 11-12).

Współcześnie innowacyjność uważana jest za główny czynnik wzrostu gospodarczego poszczególnych państw, a w ich ramach regionów i miast. Znalazło to odzwierciedlenie w powstających koncepcjach teoretycznych, zwłaszcza w nowej teorii wzrostu, teorii cyklu produkcyjnego czy modelu uczącego się regionu R. Floridy (Grosse, 2004).

W ostatnich dziesięcioleciach w literaturze przedmiotu, jak zauważa R. Domański (2005a), obserwuje się zwiększone zainteresowanie teorią wzrostu gospodarczego, w której uwzględnia się wpływ zewnętrznych zmian pobudzających wewnętrzny mechanizm wzrostu. Dochodzi tym samym do endogenizacji, w której przypisuje się większą wagę kapitałowi ludzkiemu oraz wiedzy. Ponadto przez włączenie zewnętrznych zmian techniki mechanizm wzrostu został uwolniony od czynnika niezależnego, stając się wewnętrznie spójnym 
zespołem zależności i powiązań. Dzięki wewnętrznej konsolidacji poszczególnych elementów mechanizmu wzrostu rozszerzeniu ulega przestrzeń, w której władza regionalna może wprowadzać różnorodne instrumenty rozwoju (Domański, 2005a, 2005b, 2012).

Nowa teoria wzrostu została zainicjowana przez P. Romera (1986, 1987, 1990). Zakłada ona możliwość kumulowania się czynników wzrostu, czyli osiągnięcia trwałego rozwoju oraz utrzymywania się lub nawet powiększania różnic między regionami i ośrodkami miejskimi. Długotrwały i stabilny wzrost jest określany jako rozwój endogeniczny. Opiera się on przede wszystkim na kapitale ludzkim, fizycznym i innowacyjności technologicznej. Dlatego ubogie jednostki terytorialne (regiony i miasta) mogą nadrobić opóźnienia, inwestując w kapitał ludzki oraz podnosząc poziom technologiczny. Jednocześnie rozwój endogeniczny może być wywołany sprzężeniem oddziaływania inwestycji publicznych na wzrost nakładów i produktywności w sektorze prywatnym (Grosse, 2004).

Najważniejszymi elementami gospodarki regionalnej według teorii uczącego się regionu R. Floridy są wiedza i rozwój technologiczny. Zmiana technologiczna umożliwia poprawienie wydajności gospodarczej, zapewnia przewagę konkurencyjną na rynkach zewnętrznych, modernizację struktury gospodarczej w regionach. Dlatego motorem rozwoju regionalnego są nieustanne innowacje, rozwój technologiczny oraz wiedza. Na tej podstawie Florida ukuł termin uczącego się regionu (Florida, 1995, 2000; Kosowska, Kwieciński, 2008). Zadaniem władz w myśl owej koncepcji jest stymulowanie rozwoju nauki, badań, doskonalenie kadr i aplikowanie wysokiej techniki w przedsiębiorstwach uczącego się regionu (Grosse, 2004).

Znaczenie innowacji technologicznej dla procesu rozwoju gospodarki podkreślał również w swoich pracach J. Schumpeter (1960, 1995). Ujmował on system ekonomiczny w perspektywie dynamicznej, uznając, że zasadnicze źródło zmian historycznych stanowią wynalazki techniczne, zaś rozwój gospodarczy przypomina proces twórczego niszczenia. Te nowości z jednej strony zapewniają zmianę strukturalną i rozwój, z drugiej zaś powodują zanik wcześniejszych struktur gospodarczych i społecznych. Nie wszystkie przedsiębiorstwa są przygotowane do takich zmian. Czasami bowiem są zmuszone dokonać autodestrukcji i wprowadzać całkiem nowe rozwiązania techniczne lub organizacyjne. W przeciwnym razie przestają być konkurencyjne gospodarczo. Rynek oraz postęp naukowy wymuszają takie zmiany lub marginalizują przedsiębiorstwa, a nawet całe branże i sektory produkcyjne (Mikosik, 1993; Wechta, 2003).

Poza tym według Schumpetera system gospodarczy jest głęboko osadzony w strukturach społecznych. Najważniejszym czynnikiem zmian są przedsiębiorcy, gdyż to właśnie oni wypracowują nową kombinację systemu, otwierają nowe rynki zbytu, współpracują z nowymi kooperantami oraz sięgają po nieznane wcześniej surowce i metody transportu. Zmieniają wszystkie czynniki produkcyjne decydujące o rozwoju gospodarczym, których przekształcenie zostało wywołane przez innowację technologiczną. Ważnym elementem przyspieszającym rozwój są inwestycje kapitałowe umożliwiające dokonanie skoku technologicznego. Procesy zmian mają przy tym charakter cykliczny i są powiązane z otoczeniem międzynarodowym (Grosse, 2004: 32). 


\section{ROLA INSTYTUCJI WE WSPIERANIU INNOWACYJNOŚCI}

Cechy środowiska innowacyjnego lub środowiska dla przedsiębiorczości są dość zróżnicowane (Pomykalski, 2004). Najczęściej wskazuje się na wysoki poziom kształcenia, upowszechnianie kultury przedsiębiorczości, dostępność środków finansowych oraz rozwój infrastruktury naukowej i otoczenia biznesu (Szostak, 2011).

W innym ujęciu zwraca się uwagę na zasoby naukowe i badawcze regionu, w szczególności obecność uczelni wyższych i uniwersytetów oraz wysoko wykwalifikowaną siłę roboczą, przede wszystkim doświadczonych menedżerów. Poza tym ważnymi elementami środowiska innowacyjnego są profesjonalna administracja publiczna i wysoki poziom infrastruktury technicznej, a zwłaszcza telekomunikacyjnej w regionie. Kolejnym elementem jest wysoki standard warunków życia, szczególnie jakość instytucji kulturalnych i rozrywkowych oraz dobry stan środowiska naturalnego. Poza wymienionymi wyżej dodaje się jeszcze obecność wiarygodnych instytucji finansowych oraz infrastruktury komunikacyjnej, zwłaszcza lotnisk międzynarodowych. Wskazuje się także na potrzebę dywersyfikacji bazy gospodarki regionalnej. Ważnym elementem jest także aktywna postawa władz publicznych na rzecz rozwoju i prowadzenie przez administrację dojrzałej strategii pobudzania przedsiębiorczości regionalnej. Podkreśla się również znaczenie wartości społecznych zachęcających do inicjatywy gospodarczej oraz tworzących klimat zaufania i współpracy, a także obecność tradycji przedsiębiorczości regionalnej (Grosse, 2004).

Należy podkreślić, że warunkiem powstania środowiska sprzyjającego przedsiębiorczości jest także obecność sieci kooperujących ze sobą instytucji publicznych, gospodarczych, usługowych, finansowych, społecznych i naukowych (Rejman, 2007; Szostak, 2011; Golejewska, 2012; Kaluizhanova, Osipov, 2012; Siłka, 2012). Takie powiązanie instytucjonalne pozwala stworzyć znakomite warunki do wymiany informacji, pomysłów, a następnie zbudowania zaufania i współpracy gospodarczej. Prowadzi do zjawisk innowacyjnych i rozwija nowe formy przedsiębiorczości. Współpraca jest oparta na niezwykle istotnym w tych warunkach kontakcie osobistym partnerów. Według wielu ekonomistów wszelka działalność gospodarcza zaczyna się i kończy właśnie na personalnych, często nieformalnych kontaktach menedżerów. Dlatego w okresie globalnej komunikacji tak istotne znaczenie dla rozwoju gospodarczego ma geograficzna bliskość kooperujących firm i skupienie lokalizacyjne pokrewnych sektorów przemysłowych. W ramach omawianej sieci współpracy instytucjonalnej dominującą rolę odgrywają firmy prowadzące działalność innowacyjną oraz ich kooperanci (Grosse, 2004).

Do głównych organizacji i instytucji, pobudzających rozwój regionalny i lokalny oraz często utożsamianych z procesem transferu technologii zalicza się: inkubatory przedsiębiorczości, ośrodki wspierania rozwoju, parki naukowe, centra innowacji, urzędy publiczne (lokalne i centralne), agencje techniki i technologii, instytuty naukowo-badawcze i edukacyjne oraz sieci aniołów biznesu (Oleksiuk, 2009; Szostak, 2011).

Instytucje funkcjonujące $\mathrm{w}$ dziedzinie innowacji w Polsce określane są jako ośrodki innowacji i przedsiębiorczości (Jewtuchowicz, 1996). Stanowią je zwłaszcza podmioty 
wyspecjalizowane w działaniach na rzecz rozwoju przedsiębiorczości, transferu technologii i komercjalizacji nowych technologii. Zalicza się do nich przede wszystkim ośrodki szkoleniowo-doradcze, centra transferu technologii, inkubatory przedsiębiorczości, parki technologiczne oraz lokalne fundusze pożyczkowo-poręczeniowe (Oleksiuk, 2009).

Tab. 1. Typ i charakter instytucji wspierających innowacyjność

\begin{tabular}{|c|c|}
\hline Typ instytucji & Charakter instytucji \\
\hline Ośrodki szkoleniowo-doradcze & $\begin{array}{l}\text { - prowadzą działalność szkoleniową, doradczą oraz } \\
\text { informacyjną. }\end{array}$ \\
\hline Centra transferu technologii & $\begin{array}{l}\text { - zajmują się dyfuzją i komercjalizacją nowych technologii, } \\
\text { - są odpowiedzialne za rozwijanie sieci kontaktów między } \\
\text { nauką a gospodarką, pełnią rolę jednostek pomostowych, } \\
\text { - jest to najczęściej grupa jednostek doradczych, } \\
\text { szkoleniowych oraz informacyjnych, dość zróżnicowana, } \\
\text { - przybierają postać organizacji pozarządowych } \\
\text { (stowarzyszeń, fundacji). }\end{array}$ \\
\hline Inkubatory przedsiębiorczości & $\begin{array}{l}\text { - oferują kompleksową pomoc doradczą na start } \\
\text { przedsiębiorstw, } \\
\text { - organizują i przyspieszają ich wzrost, } \\
\text { - oferują wynajem lokali dla nowo powstających } \\
\text { przedsiębiorstw w początkowym okresie ich } \\
\text { funkcjonowania. }\end{array}$ \\
\hline Parki technologiczne & $\begin{array}{l}\text { - najczęściej są to zorganizowane kompleksy przemysłowe } \\
\text { skupiające na określonym terenie instytucje naukowo- } \\
\text {-badawcze oraz otoczenie biznesu w zakresie } \\
\text { finansowania, doradztwa i wspierania rozwoju firm } \\
\text { innowacyjnych, } \\
\text { - ich główna rola sprowadza się do: pomocy w zakładaniu } \\
\text { nowych firm, przyciągania kapitału z zewnątrz, } \\
\text { wspierania rozwoju firm istniejących w regionie, rozwoju } \\
\text { innowacji i przedsiębiorczości oraz dystrybucji osiągnięć } \\
\text { naukowych, } \\
\text { - są tworzone celem promocji formalnych i operacyjnych } \\
\text { więzi z uczelniami wyższymi i instytutami badawczymi, } \\
\text { - ułatwiają dostęp do niezbędnego ludzkiego i fizycznego } \\
\text { kapitału dla nowych firm wykorzystujących technologie, } \\
\text { - kreują środowisko sprzyjające transferowi technologii } \\
\text { oraz umiejętnościom biznesowym. }\end{array}$ \\
\hline Fundusze pożyczkowo-poręczeniowe & $\begin{array}{l}\text { - stanowią je raczej nienastawione na zysk jednostki } \\
\text { parabankowe świadczące pomoc finansową } \\
\text { w formie grantów i preferencyjnych pożyczek dla } \\
\text { firm rozpoczynających działalność gospodarczą } \\
\text { oraz gwarancji i poręczeń dla małych rozwojowych } \\
\text { firm, nieposiadających wymaganych zabezpieczeń } \\
\text { kredytowych. }\end{array}$ \\
\hline
\end{tabular}

Źródło: opracowanie własne na podstawie: Grzyb, 2008; Surdej, Wach, 2008; Oleksiuk, 2009 
Główna rola scharakteryzowanych instytucji polega na wieloaspektowym wspieraniu innowacyjności. Zasadniczym priorytetem działania wymienionych instytucji jest komercjalizacja technologii, czyli ogół czynności prawnych i finansowych, związanych z jakością proponowanych nowych rozwiązań. To celowe, ukierunkowane przeniesienie wiedzy do praktyki życia gospodarczego. Obecność tych instytucji przyczynia się również do rozwoju miast, w których są one zlokalizowane (Grzyb, 2008).

Poza tym ułatwiają one transfer technologii z lokalnych ośrodków badawczych i uczelni do firm czy organizacji funkcjonujących w danej instytucji. Transfer technologii to proces przystosowywania wyników badań naukowych, patentów lub oryginalnych pomysłów do ich praktycznego zastosowania w produkcji. Obejmuje: różnego rodzaju prace rozwojowe i wdrożeniowe, polegające na wykonaniu modeli i prototypów lub sprawdzaniu przebiegu proponowanego procesu technologicznego, określenie cech użytkowych i ekonomicznych proponowanych nowych wyrobów lub nowych procesów technologicznych i badań jakościowych, analizę rynku, wybór najwłaściwszego producenta, ustalenie zasad finansowania dla producenta i uczelni (twórcy technologii) oraz uruchomienie produkcji (Grzyb, 2008).

\section{INSTYTUCJONALNE WSPARCIE INNOWACYJNOŚCI W WOJEWÓDZTWIE ŚLĄSKIM}

Instytucje wspierające proces komercjalizacji technologii $\mathrm{w}$ województwie śląskim to zgodnie z projektem Śląski Portal na Rzecz Innowacji: jednostki badawczo-rozwojowe, instytucje otoczenia biznesu (zwłaszcza agencje rozwoju lokalnego lub regionalnego, fundacje o podobnym profilu działalności), fundusze pożyczkowe, fundusze poręczeń kredytowych, fundusze kapitału zalążkowego, parki przemysłowe i parki naukowo-technologiczne, inkubatory technologiczne oraz inkubatory przedsiębiorczości. Poniżej dokonano zestawienia oferty i kierunków wsparcia wybranych instytucji w województwie śląskim.

Tab. 2. Działalność wybranych instytucji w województwie śląskim

\begin{tabular}{|c|c|}
\hline Charakter instytucji & Oferta \\
\hline $\begin{array}{l}\text { Ośrodek Badawczo-Rozwojowy Urządzeń } \\
\text { Mechanicznych OBRUM sp. z o.o. w Gliwicach } \\
\text { jest jedyną tego typu przemysłową jednostką } \\
\text { badawczo-rozwojową w Polsce. } \\
\text { OBRUM sp. z o.o. podejmuje się realizacji } \\
\text { nowych projektów, mogących służyć } \\
\text { zaspokojeniu przyszłych potrzeb wojska, } \\
\text { związanych z utrzymaniem i podnoszeniem } \\
\text { gotowości do zapewnienia bezpieczeństwa } \\
\text { państwa i udziału armii w operacjach } \\
\text { sojuszniczych. }\end{array}$ & $\begin{array}{l}\text { - kompleksowe opracowywanie projektów } \\
\text { różnego rodzaju maszyn, } \\
\text { - opracowywanie dokumentacji konstrukcyjnej } \\
\text { zespołów i elementów maszyn, } \\
\text { - projektowanie systemów automatyki (układy } \\
\text { sterowania), } \\
\text { - projektowanie systemów dystrybucji mocy } \\
\text { w pojazdach. }\end{array}$ \\
\hline
\end{tabular}




\begin{tabular}{|c|c|}
\hline $\begin{array}{l}\text { Centrum Przedsiębiorczości S.A. z siedzibą } \\
\text { w Woli rozpoczęła funkcjonowanie we wrześniu } \\
1999 \text { roku. Podstawowym celem spółki jest } \\
\text { przeciwdziałanie bezrobociu przez wspomaganie } \\
\text { rozwoju małych i średnich przedsiębiorstw } \\
\text { w regionie, w którym dotychczas dominowała } \\
\text { monokultura górnicza. }\end{array}$ & $\begin{array}{l}\text { - wdrażanie i komercjalizacja technologii } \\
\text { i produktów innowacyjnych, } \\
\text { - wsparcie w zakresie podjęcia lub rozwoju } \\
\text { działalności badawczo-rozwojowej w mikro-, } \\
\text { małych i średnich przedsiębiorstwach, } \\
\text { - usługi informacyjne, szkoleniowe i doradcze } \\
\text { w ramach projektów finansowanych ze } \\
\text { środków krajowych i zagranicznych. }\end{array}$ \\
\hline $\begin{array}{l}\text { Stowarzyszenie „Bielskie Centrum } \\
\text { Przedsiębiorczości” jest organizacją } \\
\text { pozarządową typu non-profit, działającą } \\
\text { od kwietnia } 1994 \text { roku. Jej głównym celem } \\
\text { jest wspieranie rozwoju indywidualnej } \\
\text { przedsiębiorczości, aktywne zwalczanie } \\
\text { bezrobocia przez udzielanie zróżnicowanej } \\
\text { pomocy osobom bezrobotnym, podejmowanie } \\
\text { i wspieranie inicjatyw społecznych } \\
\text { i gospodarczych w zakresie wspomagania } \\
\text { przedsiębiorczości, rozwój potencjału } \\
\text { gospodarczego regionu oraz poprawa jakości } \\
\text { życia społeczności lokalnej. }\end{array}$ & $\begin{array}{l}\text { - usługi informacyjne, doradcze i porady prawne } \\
\text { dla przedsiębiorców, } \\
\text { - kompleksowa pomoc w zakresie poszukiwania } \\
\text { źródeł finansowania działalności szkoleniowej, } \\
\text { - możliwość korzystania z inkubatora } \\
\text { przedsiębiorczości, funduszu pożyczkowego, } \\
\text { punktu konsultacyjnego oraz regionalnego } \\
\text { ośrodka specjalizującego się w doradztwie } \\
\text { w zakresie pozyskiwania środków unijnych. }\end{array}$ \\
\hline $\begin{array}{l}\text { Sosnowiecki Park Naukowo-Technologiczny } \\
\text { stwarza korzystne warunki przedsiębiorstwom, } \\
\text { instytucjom wsparcia przedsiębiorczości, } \\
\text { placówkom naukowym i badawczym oraz } \\
\text { szkolno-edukacyjnym, zapewniając odpowiednią } \\
\text { infrastrukturę wraz z niezbędnym zapleczem } \\
\text { technicznym oraz wsparcie merytoryczne. Jego } \\
\text { misją jest stymulowanie rozwoju gospodarczego } \\
\text { Sosnowca i województwa śląskiego przez } \\
\text { przyciąganie, wspieranie i rozwój innowacyjnych } \\
\text { przedsiębiorstw działających w sektorze } \\
\text { nowoczesnych technologii. }\end{array}$ & $\begin{array}{l}\text { - wynajem nieruchomości, zapewnienie } \\
\text { preferencyjnego dostępu do infrastruktury } \\
\text { (w tym pomieszczenia zespołu konferencyjno- } \\
\text {-szkoleniowego), } \\
\text { - obsługa biurowa, w szczególności dostęp do: } \\
\text { usług recepcyjnych, telefonu, kserokopiarki, } \\
\text { komputera i internetu, } \\
\text { - dostęp do atrakcyjnych instrumentów } \\
\text { finansowych (poręczeń kredytowych } \\
\text { i preferencyjnych pożyczek), } \\
\text { - usługi szkoleniowe i doradcze w zakresie } \\
\text { pozyskania środków finansowych na rozwój, } \\
\text { - wsparcie w nawiązywaniu kontaktów } \\
\text { biznesowych, } \\
\text { - wymiana doświadczeń między podmiotami } \\
\text { gospodarczymi, } \\
\text { - współpraca z uczelniami wyższymi, } \\
\text { - usługi promocyjne. }\end{array}$ \\
\hline
\end{tabular}

Źródło: opracowanie własne na podstawie http://spnri.nazwa.pl/index.php

Jak wynika z analizy danych w województwie śląskim, 28 miast posiada przynajmniej jedną tego typu instytucję. Ich rola sprowadza się głównie do doradztwa, wspierania w zakresie pozyskania funduszy unijnych oraz organizacji szkoleń i wynajmu nieruchomości. Zdecydowana większość tych ośrodków to miasta należące do Górnośląskiego Związku Metropolitalnego lub położone blisko tego zespołu. W tej grupie jednak aż 15 miast posiada najwyżej dwie tego typu jednostki. Do czołówki należą przede wszystkim największe 
miasta, m.in. stolica regionu - Katowice z 15 instytucjami. Drugim najlepiej wyposażonym ośrodkiem są Gliwice, kolejnym zaś Bielsko-Biała, które pod tym względem jawi się jako zdecydowany lider południowej części województwa. Wiąże się to przede wszystkim z obecnością wielu przedsiębiorstw (zarówno mniejszych, rozwijanych przez lokalną społeczność, jak i dużych przedsiębiorstw międzynarodowych, które rozpoczęły produkcję). Wpływ na wysoką pozycję Bielska-Białej ma także duża liczba szkół wyższych i instytucji badawczo-rozwojowych, jak na ośrodek o takiej liczbie mieszkańców (Siłka, 2012). Drugim liczącym się miastem w południowej części województwa śląskiego jest Cieszyn. Z kolei na północy regionu dobrze wyposażonym w instytucje miastem jest Częstochowa (Trzepacz, 2010: 84-85).

\section{WNIOSKI}

Niewątpliwie wsparcie rozwoju i zakładania podmiotów gospodarczych opartych na wiedzy, nowych ideach, pomysłach, kreatywności jest niezwykle istotne dla rozwoju miast. Pomocniczą, doradczą, szkoleniową oraz finansową pomoc oferuje wiele instytucji. Ich liczba w poszczególnych ośrodkach miejskich jest zróżnicowana. Należy wyraźnie zaznaczyć ich zróżnicowanie przestrzenne i ilościowe. Wiele miast takich instytucji w ogóle nie posiada.

Poza tym ważna jest skuteczna kooperacja między sektorem naukowo-badawczym i biznesowym, która pozwoli na transfer nowych technologii. Korzyści gospodarcze wynikające z niej są wielowymiarowe: rozwój nauki i badań, prowadzenie działalności naukowo-badawczej w nowych dziedzinach, mogących przyczynić się do podniesienia rangi miasta $\mathrm{w}$ regionie, zmianie jego dotychczasowej funkcji, rozwój przemysłu opartego na najnowszych wynikach badań naukowych na bardzo korzystnych warunkach finansowych. Jednocześnie rozwija się efektywna współpraca nauki z przemysłem, przynosząca korzyści obu stronom i wzmacniająca potencjał gospodarczy kraju. Korzystnym rezultatem współpracy jest również rozwój nowoczesnego szkolnictwa, które musi sprostać wymogom nowoczesnego kształtowania i przygotowywania kadr dla nowoczesnej nauki i nowoczesnego przemysłu. Warto także podkreślić, że skuteczne wykorzystanie badań naukowych wpływa na tworzenie nowoczesnych produktów i usług, które mogą być zbywane na rynku lokalnym, ale także globalnie w świecie, przynosząc gospodarce kraju przychody z podatków i eksportu. W przypadku miast nowoczesna nauka i przemysł kreują strukturę zatrudnienia (zawody w dużym stopniu oparte na wiedzy) i wpływają na niski poziom bezrobocia, co w skali kraju przekłada się na wysoki standard życia i zadowolenie ludności.

\section{Literatura}

Campion, M. (2012). Rola samorzadu we wspieraniu lokalnej i regionalnej przedsiębiorczości. Kraków: Wydawnictwo Naukowe UP.

Domański, R. (2012). Ewolucyjna gospodarka przestrzenna. Poznań: Wydawnictwo Naukowe UEK. 
Domański, R. (2005a). Korporacje ponadnarodowe a miejsce (region). Biuletyn KPZK PAN, 219, 130146.

Domański, R. (2005b). Samowzmacnianie rozwoju miast i regionów w gospodarce intensyfikującej wykorzystanie wiedzy. Wnioski z nowej teorii wzrostu endogenicznego. Przegląd Geograficzny, 77 (2), 131-138.

Dworak, E. (2012). Gospodarka oparta na wiedzy w Polsce. Ocena, uwarunkowania, perspektywy. Łódź: Wydawnictwo Uniwersytetu Łódzkiego.

Florida, R. (1995). Toward the Learning Region, Futures, 27 (5), s. 527-536.

Florida, R. (2000). The Learning Region, W: Z.J. Acs (ed.), Regional Innovation, Knowledge and Global Change. London: Printer.

Golejewska, A. (2012). Innowacyjność a konkurencyjność regionalna krajów Grupy Wyszehradzkiej w latach 1999-2008. Prace Komisji Geografii Przemystu Polskiego Towarzystwa Geograficznego, $19,93-115$.

Grosse, T.G. (2004). Polityka regionalna Unii Europejskiej. Przykład Grecji, Włoch, Irlandii i Polski. Warszawa: Instytut Spraw Publicznych.

Grzyb, U. (2008). Centra transferu technologii jako czynnik rozwoju gospodarki opartej na wiedzy. Przedsiębiorczość - Edukacja, 4, 70-74.

Janczewski, J. (2006). Innowacje jako narzędzie przedsiębiorczości małej firmy na przykładzie usług motoryzacyjnych. Przedsiębiorczość - Edukacja, 2, 27-40.

Jasiński, A.H. (1997). Innowacje i polityka innowacyjna, Białystok: Wydawnictwo Uniwersytetu w Białymstoku.

Jewtuchowicz, A. (1996). Powstawanie środowiska i sieci innowacji. Teorie i rzeczywistość. W: K.B. Matusiak, K. Zasiadły, T. Broczkowski, M. Pietraszewski (red.), Ośrodki innowacji i przedsiębiorczości w Polsce. Poznań-Warszawa: Polska Agencja Rozwoju Przedsiębiorczości, 59-74.

Kaluizhnova, N., Osipov, M. (2012). Institutional Factors of Innovation-Oriented Regional Development. Prace Komisji Geografii Przemystu Polskiego Towarzystwa Geograficznego, 19, 116-125.

Kochmańska, M. (2011). Zarządzanie innowacjami w małych i średnich przedsiębiorstwach w warunkach globalizacji. Przedsiębiorczość - Edukacja, 7, 90-102.

Kosowska, A., Kwieciński, L. (2008). Region uczący się na przykładzie Øresund. W: E. Stadtmüller, K. Jędrzejczyk-Kuliniak, L. Kwieciński, B. Michalski (red.), Regionalizacja w stosunkach międzynarodowych. Toruń: Wydawnictwo Adam Marszałek, 422-438.

Maśloch, P. (2005). Globalizacja i jej wpływ na rozwój współczesnej cywilizacji. Przedsiębiorczość Edukacja, 1, 17-26.

Mikosik, S. (1993). Teoria rozwoju gospodarczego Josepha A. Schumpetera. Warszawa: Wydawnictwo Naukowe PWN.

Oleksiuk, A. (2009). Konkurencyjność regionów a parki technologiczne i klastry przemysłowe. Bydgoszcz-Warszawa: Oficyna Wydawnicza Branta.

Pomykalski, A. (2004). Procesy integracyjne w zarządzaniu innowacjami w regionie. W: A. Jewtuchowicz (red.), Wiedza, innowacyjność, przedsiębiorczość a rozwój regionów. Łódź: Wydawnictwo Uniwersytetu Łódzkiego, 187-195.

Rachwał, T. (2012). Innowacyjność przedsiębiorstw przemysłowych jako czynnik rozwoju miast. Z. Makieła, A. Szromnik (red.), Miasto innowacyjne. Wiedza - przedsiębiorczość - marketing, Studia KPZK PAN, 141, 135-152.

Rejman, K. (2007). Wpływ innowacyjności na efektywność współczesnych przedsiębiorstw. Przedsiębiorczość - Edukacja, 3, 220-224.

Romer, P.M. (1987). Growth Based on Increasing Returns due to Specialization. American Economic Review: Papers and Proceedings, 77 (2), 56-62.

Romer, P.M. (1990). Endogenous Technological Change. Journal of Political Economy, 98 (5), part 2, 71-102. 
Romer, P.M. (1986). Increasing Returns and Long-run Growth. Journal of Political Economy, 94 (5), $1002-1037$.

Schumpeter, J. (1960). Teoria rozwoju gospodarczego. Warszawa: Państwowe Wydawnictwo Naukowe.

Schumpeter, J. (1995). Kapitalizm, socjalizm, demokracja. Warszawa: Wydawnictwo Naukowe PWN.

Siłka, P. (2012). Typologia miast ze względu na potencjał innowacyjny. Prace Komisji Geografii Przemystu Polskiego Towarzystwa Geograficznego, 19, 61-73.

Surdej, A., Wach, K. (2008). Rola parków naukowo-technologicznych w rozwoju małych i średnich przedsiębiorstw. Przedsiębiorczość - Edukacja, 4, 75-81.

Szostak, E. (2011). Dostosowania w zakresie polityki innowacyjnej w Unii Europejskiej. W: M. Klamut (red.), Konkurencyjność i spójność w polityce rozwoju Unii Europejskiej. Wrocław: Wydawnictwo Uniwersytetu Ekonomicznego, 66-86.

Trzepacz, P. (2010). Funkcje i innowacyjność miast województwa śląskiego. W: A. Sobala-Gwosdz (red.), Badanie trendów rozwojowych w województwie śląskim poprzez wyznaczenie ośrodków wzrostu i obszarów stagnacji. Bielsko-Biała: Strada Consulting Piotr Kurowski, 73-88.

Wechta, P. (2003). Socjologia i kryptosocjologia Josepha Schumpetera. Poznań: Wydawnictwo Naukowe UAM.

Sabina Sanetra-Pólgrabi, dr, Uniwersytet Pedagogiczny w Krakowie.

Urodzona w 1981, absolwentka politologii na Uniwersytecie Pedagogicznym im. KEN w Krakowie. Zajmuje się problematyką współpracy transgranicznej i zagadnieniami rozwoju regionalnego i lokalnego. Przygotowuje swoją pierwszą publikację pt. Funkcjonowanie euroregionów na pograniczu południowym Polski po 1993 roku (analiza porównawcza trzech euroregionów: Śląsk Cieszyński, Beskidy $i$ Tatry).

Sabina Sanetra-Pólgrabi (born in 1981), a graduate of Political Science at the Pedagogical University of Cracow. She is occupied with the issues of cross-border cooperation and the issue of regional and local self-government. She is in the course of preparing her first publication titled Functioning of Euroregions in the Polish Southern Borderland after the Year 1993 (the comparative analysis of three euroregions: Cieszyn Silesia, the Beskids and Tatra Mountains).

adres/address: Uniwersytet Pedagogiczny w Krakowie, ul. Podchorążych 2, 30-084 Kraków, Polska

e-mail: sab_san@poczta.onet.pl 